\title{
Exceptional crocodylomorph biodiversity of "La Cantalera" site (lower Barremian; Lower Cretaceous) in Teruel, Spain
}

\author{
Eduardo Puértolas-Pascual, Raquel Rabal-Garcés, and José Ignacio Canudo
}

\begin{abstract}
The palaeontological site of La Cantalera in Teruel, Spain (Blesa Formation, Lower Cretaceous) can be characterized as the site with the greatest biodiversity of vertebrates (32 taxa) from the lower Barremian of the Iberian Peninsula. Remains of amphibians, lizards, turtles, crocodiles, pterosaurs, dinosaurs and mammals have been recovered. The most common taxa are crocodylomorphs, and their most abundant remains are small isolated teeth. Six morphotypes have been identified, which may correspond to at least four different sympatric crocodylomorph taxa. This site presents a similar assemblage to other European Lower Cretaceous sites, with morphotypes that may correspond to the families Goniopholididae, Bernissartiidae, Atoposauridae and multiple ziphodont crocodylomorphs. The crocodylomorph assemblage of La Cantalera is characterized by the absence of large individuals and presents a wide variety of dental morphologies adapted to diets ranging from generalist to highly specialized. This rich biodiversity could be due to concentration of vertebrates into restricted flooded areas during dry seasons within a marsh ecosystem. Furthermore, La Cantalera could also be close to a nesting area, which would explain the abundance of small-sized individuals and the presence of fossil crocodiloid eggshells.
\end{abstract}

Eduardo Puértolas-Pascual. Grupo Aragosaurus-IUCA, Departamento de Ciencias de la Tierra, Facultad de Ciencias, Universidad de Zaragoza, Calle Pedro Cerbuna 12, 50009 Zaragoza (Spain). puertola@unizar.es

Raquel Rabal-Garcés. Grupo Aragosaurus-IUCA, Departamento de Ciencias de la Tierra, Facultad de Ciencias, Universidad de Zaragoza, Calle Pedro Cerbuna 12, 50009 Zaragoza (Spain)

raquelrabal@hotmail.com

José Ignacio Canudo. Grupo Aragosaurus-IUCA, Departamento de Ciencias de la Tierra, Facultad de

Ciencias, Universidad de Zaragoza, Calle Pedro Cerbuna 12, 50009 Zaragoza (Spain)

jicanudo@unizar.es

Keywords: Cretaceous, Lower; Crocodylomorpha; teeth; palaeoecology; palaeobiodiversity; Iberian Range

PE Article Number: 18.2.28A

Copyright: Society for Vertebrate Paleontology June 2015

Submission: 2 October 2014. Acceptance: 22 May 2015

Puértolas-Pascual, Eduardo, Rabal-Garcés, Raquel, and Canudo, José Ignacio. 2015. Exceptional crocodylomorph biodiversity of "La Cantalera" site (lower Barremian; Lower Cretaceous) in Teruel, Spain. Palaeontologia Electronica 18.2.28A: 1-16 palaeo-electronica.org/content/2015/1229-biodiversity-of-la-cantalera 


\section{INTRODUCTION}

There are several studies of palaeontological sites with vertebrate accumulations in the Barremian (Lower Cretaceous) of the Iberian Peninsula (Rauhut, 2002; Cuenca-Bescós and Canudo, 2003; Ruiz-Omeñaca et al., 2004; Buscalioni et al., 2008; Canudo et al., 2002a, 2010). La Cantalera (Josa, Teruel) is of great interest because it is one of the macro- and micro-vertebrate accumulation sites with the greatest palaeobiodiversity in the Lower Cretaceous of Europe, with at least 32 different taxa (Table 1) (Canudo et al., 2010). The vertebrate assemblage is composed almost exclusively of terrestrial and amphibious organisms that inhabited the vicinity of the site. La Cantalera has been considered to provide a good temporal sample of the faunal community that inhabited the area (Canudo et al., 2010; Gasca et al., 2014).

The most abundant skeletal remains found in La Cantalera site are isolated teeth (RuizOmeñaca et al., 1997; Canudo et al., 2004, 2010). The most common remains are crocodylomorph teeth. Together with disarticulated postcranial remains, these fossils testify to the high palaeobiodiversity of crocodylomorphs at this site. Teeth belonging to multituberculate mammals, peripheral plates of turtles, cranial and postcranial remains of amphibians and lizards, isolated pterosaur teeth and a single vertebra from an osteichthyan fish have also been identified. The greatest biodiversity at the site is associated with non-avian dinosaurs, with identified isolated teeth and postcranial remains from: ornithopods, theropods, sauropods and thyreophorans (Ruíz-Omeñaca et al., 1997, 2001; Badiola et al., 2008; Canudo et al., 2010). Additional eggshell fossils have been recovered from the site, belonging to turtles, non-avian dinosaurs and crocodylomorphs (Moreno-Azanza et al., 2009, 2014; Canudo et al., 2010). Furthermore, coprolites with six different morphologies have been identified (Ruíz-Omeñaca et al., 2001).

There have been relatively few studies of crocodylomorphs from the Lower Cretaceous of the Iberian Range (Buscalioni and Sanz, 1984, 1987, 1990b; Buscalioni et al., 1984, 2008, 2013; Sanz et al., 1984; Brinkmann, 1992; Ortega et al., 1996; Ortega, 2004; Puértolas-Pascual et al., 2015). These studies have been undertaken over the past three decades on the basis of isolated remains and specimens represented by cranial and postcranial material, primarily from the sites of Teruel (Josa, Galve, Ariño and Andorra) and Cuenca (Las Hoyas, Uña and Buenache de la Sierra).
Referring to Teruel, several studies of the Barremian have been carried out at palaeontological sites within the Galve syncline on the basis of teeth and isolated postcranial and cranial fragments (Buscalioni and Sanz, 1984, 1987; Sanz et al., 1984; Ruíz-Omeñaca et al., 2004). In these papers the crocodylomorph material was assigned to Mesoeucrocodylia indet., Neosuchia indet., cf. Machimosaurus sp., Goniopholididae, Atoposauridae and Bernissartia. Furthermore, a complete skull attributed to Bernissartia fagesii Dollo, 1883 was also described (Buscalioni et al., 1984; Buscalioni and Sanz, 1990b).

In Josa, where the site of La Cantalera (lower Barremian) is located, a preliminary study was carried out, focusing on a large sample of crocodylomorph teeth. This allowed the teeth to be grouped into different morphotypes, which were assigned to cf. Theriosuchus sp., Bernissartiidae indet., Goniopholididae indet. and cf. Lisboasaurus sp. (Canudo et al., 2010).

More recently, new studies have been carried out in more modern sediments in the Escucha Formation (lower Albian), close to the localities of Andorra and Ariño. In these sites two new species of goniopholidids have been described (Alcalá et al., 2012; Puértolas-Pascual et al., 2012, 2015; Buscalioni et al., 2013; Puértolas-Pascual and Canudo, 2013).

There are also several other studies based on isolated teeth from the Lower Cretaceous of Europe: the United Kingdom, France, Denmark, Sweden, Belgium and Portugal. Almost all of these sites have a similar assemblage composed of Goniopholididae, Bernissartiidae, Atoposauridae and other less abundant forms (Buscalioni et al., 2008; Schwarz-Wings et al., 2009).

In this context, the aim of the present paper is to review and describe the crocodylomorph tooth assemblage recovered from La Cantalera site in order to determine the variability and biodiversity of the site and compare this with other European sites of similar age.

\section{GEOGRAPHICAL AND GEOLOGICAL SETTING}

The palaeontological site of La Cantalera is situated in the northeast of the Iberian Peninsula, near the small locality of Josa in Teruel, Spain (Figure 1.1).

Geologically, the site is located in the Mesozoic Oliete Subbasin, which is one of the seven subbasins belonging to the Late Cretaceous Maestrazgo Basin (Soria de Miguel, 1997; Salas et al., 2001). This is located in the eastern part of the lbe- 
TABLE 1. Faunal assemblage of La Cantalera. Colors show the ecological affinity of each taxon, aquatic in blue, amphibious in green and terrestrial in brown. Modified from Canudo et al., 2010 and Ruiz-Omeñaca et al., 1997.

\begin{tabular}{|c|c|c|c|}
\hline Class & Order/Superorder & Sub/Infraorder & Taxa \\
\hline \multirow[t]{2}{*}{ Charophyceae } & Charales & Quinquespiralia & Atopochara trivolvis triquetra Grambast, 1968 \\
\hline & & & Pseudoglobator sp. \\
\hline \multirow[t]{2}{*}{ Gastropoda } & Caenogastropoda & & Viviparidae indet. \\
\hline & Basomatophora & & Basomatophora indet. \\
\hline Ostracoda & Podocopida & Podocopina & Cypridea (Ulwellia) soriana Kneuper-Haack, 1966 \\
\hline Osteichtyes & & & Teleostei indet. \\
\hline \multirow[t]{2}{*}{ Lissamphibia } & & & Albanerpetonidae indet. \\
\hline & Anura & & Discoglossidae indet. \\
\hline \multirow[t]{25}{*}{ "Reptilia" } & Chelonia & & Pleurosternidae? indet. \\
\hline & Crocodylomorpha & & Goniopholididae? \\
\hline & & & Bernissartiidae? \\
\hline & & & Theriosuchus sp. \\
\hline & & & Mesoeucrocodylia indet. \\
\hline & Squamata & Lacertilia & Paramacellodidae? indet. \\
\hline & Pterosauria & & Istiodactylidae? indet. \\
\hline & & & Ornithocheiridae? indet. \\
\hline & Ornithischia & Ornithopoda & Iguanodontoidea indet. \\
\hline & & & Hadrosauroidea? indet. \\
\hline & & & "Hypsilophodontidae" indet. \\
\hline & & & Rhabdodontidae? indet. \\
\hline & & Thyreophora & Polacanthidae indet. \\
\hline & Saurischia & Sauropoda & Euhelopodidae indet \\
\hline & & Theropoda & Baryonychinae indet. \\
\hline & & & Carcharodontosauridae? indet. \\
\hline & & & aff. Paronychodon sp. \\
\hline & & & Maniraptora indet. 1 \\
\hline & & & Maniraptora indet. 2 \\
\hline & & & Maniraptora indet. 3 \\
\hline & & & Dromaeosaurinae indet. 1 \\
\hline & & & Dromaeosaurinae indet. 2 \\
\hline & & & Dromaeosaurinae indet. 3 \\
\hline & & & Velociraptorinae indet. \\
\hline & & & Avialae? indet. \\
\hline \multirow[t]{4}{*}{ Mammalia } & Multituberculata & & $\begin{array}{c}\text { Cantalera abadi Badiola, Canudo and Cuenca- } \\
\text { Bescós, } 2008\end{array}$ \\
\hline & & & Eobaatar sp. \\
\hline & & & "Plagiaulacida" indet. \\
\hline & & & Plagiaulacidae/Eobaataridae indet. \\
\hline
\end{tabular}

rian Range and borders the Tertiary basins of the Ebro River in the north and the locality of Montalbán in the south (Figure 1.1). During the Mesozoic, the Iberian Basin underwent a major extension related to the opening of the Atlantic (Salas et al., 2001). The Oliete Subbasin was formed during the second rifting stage that began in the Early Cretaceous, when the carbonate platform of the central sector of the Iberian Basin was fractured as a result of the process of extension, creating several subbasins (Soria de Miguel, 1997; Salas et al., 2001). 


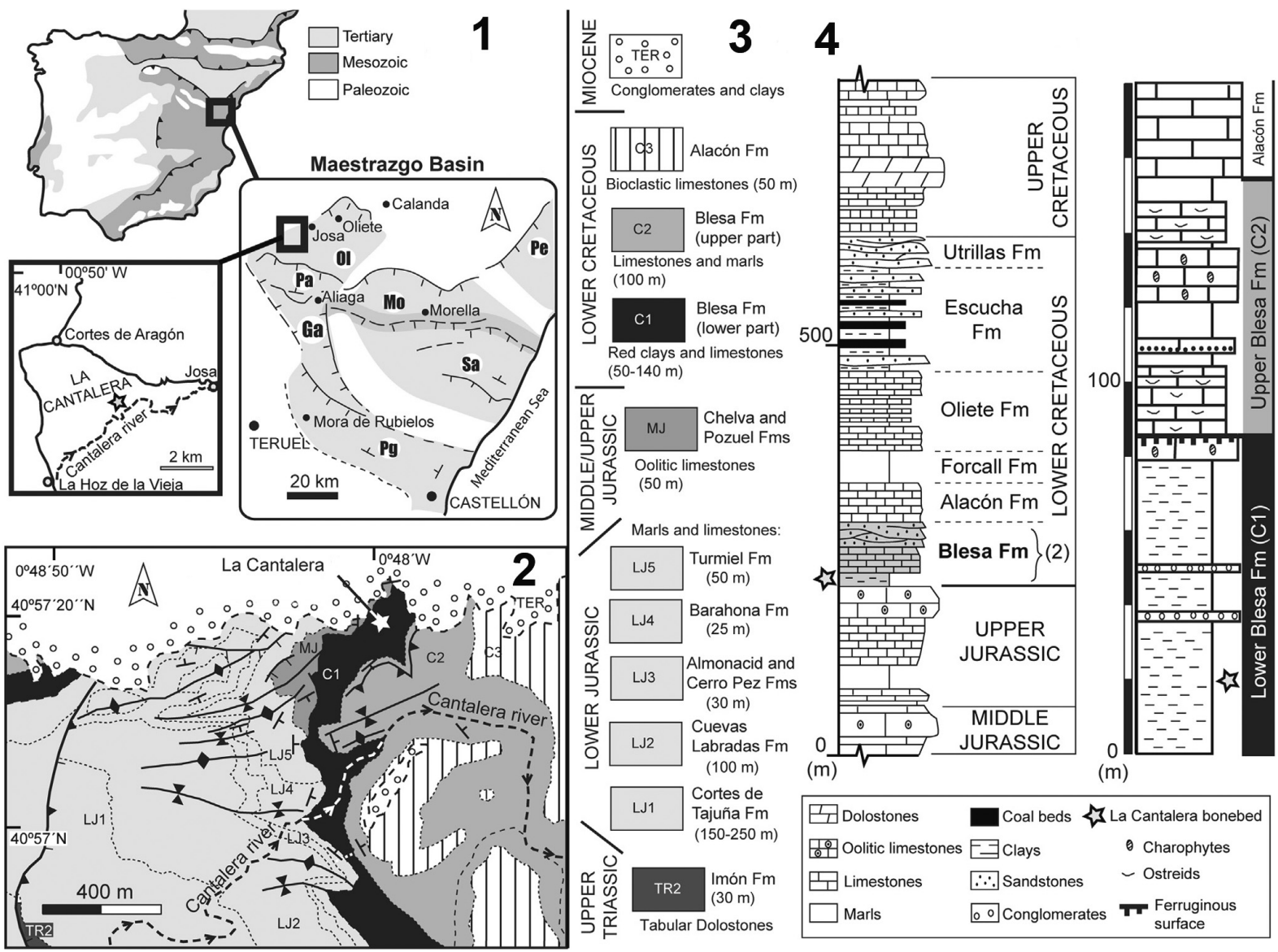

FIGURE 1. Geographical and geological setting of La Cantalera site (early Barremian, Teruel, Spain). 1, Geological map of the Iberian Peninsula with detailed location of the site of La Cantalera and its position within the Maestrazgo Basin (Ol: Oliete, Pa: Las Parras, Ga: Galve, Mo: Morella, Pe: Perelló, Sa: Salzedella, Pg: Peñagolosa). 2, Geological map of the area of La Cantalera. 3, Local geological units. 4, Stratigraphic column and position of La Cantalera. Modified from Canudo et al., 2010.

The Lower Cretaceous of the Oliete Subbasin is characterized by four megasequences: the Margas y Calizas de Blesa Formation; the Calizas de Alacón Formation; the Margas de Forcall Formation; and the Calizas de Oliete Formation (Soria de Miguel, 1997) (Figure 1.2-4). The site of La Cantalera forms part of the typical "Wealden facies" of the Lower Cretaceous. More specifically, it is located within the gray clays of the lower part of the Blesa Formation (Figure 2), which has traditionally been considered upper Hauterivian / lower Barremian in age (Soria et al., 1995; Canudo et al., 2002b; Aurell et al., 2004) due to the presence of the charophyte Atopochara trivolvis triquetra Grambast, 1968. However, the presence of this species at the base of the Blesa Formation indicates a lower Barremian age, as in the upper part of the Castellar Formation at Galve (Canudo et al., 2012).
In the area around Josa, the Blesa Formation displays a complex sedimentary evolution. Continental sedimentation predominates at the bottom, with alluvial, lacustrine and palustrine deposits (Figure 2), while the top shows facies of marshes and coastal lagoons. The site of La Cantalera has been interpreted as mudflat deposits associated with swampy areas with periodic droughts in an area of marshy vegetation. The significant concentration of vertebrate remains at the site of La Cantalera can perhaps be explained by the small size and isolated nature of the swampy domains, which might have attracted animals for feeding (RuízOmeñaca et al., 1997; Aurell et al., 2004).

\section{MATERIALS AND METHODS}

The materials included in this study were recovered by washing and sieving (sieves of 2, 1 and $0.5 \mathrm{~mm}$ mesh) over three tons of sediment 


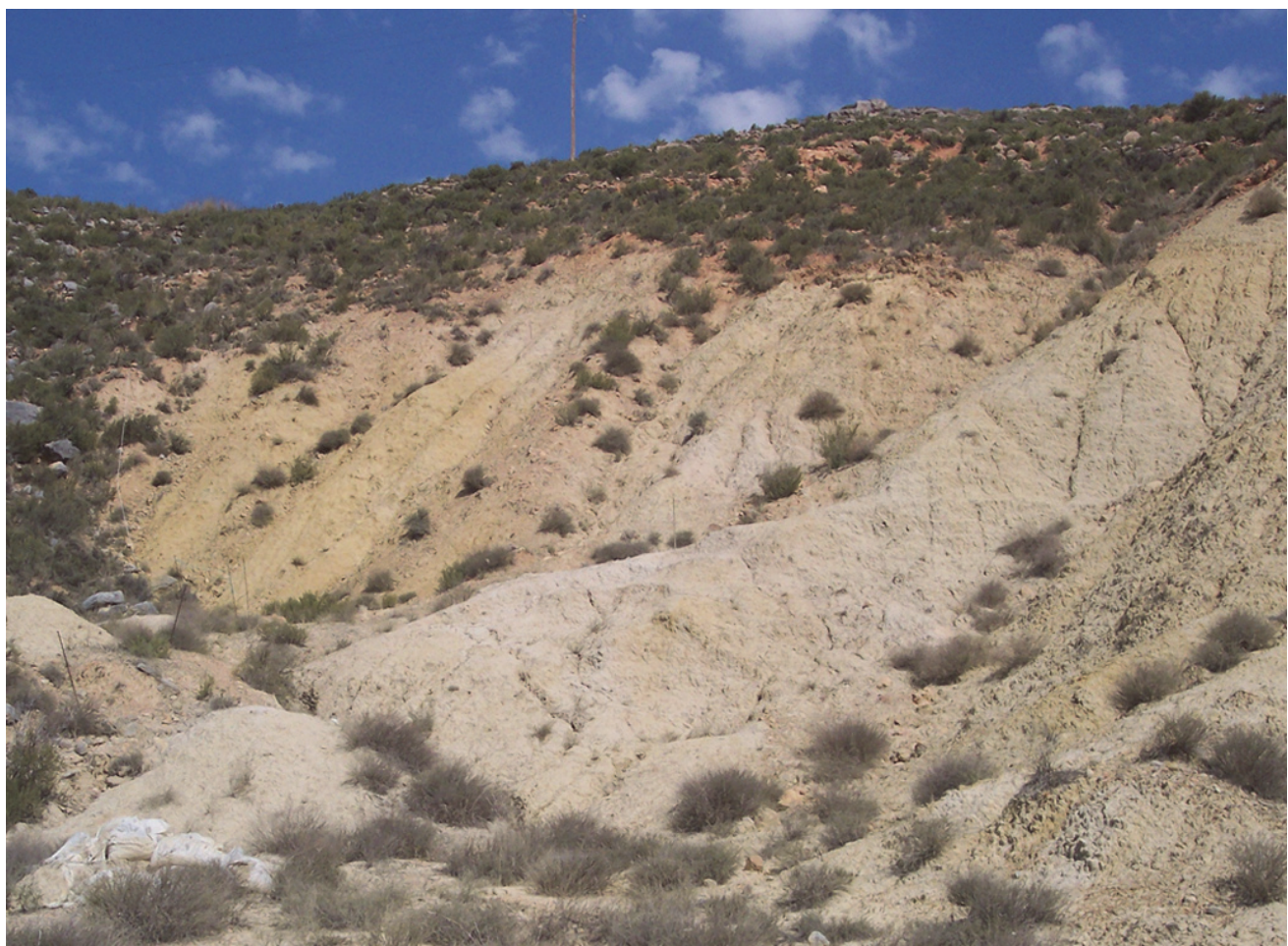

FIGURE 2. General view of La Cantalera site, showing the gray clays of the lower part of the Blesa Formation.

recovered during several field campaigns from 1997-2000. The study includes a total of 365 crocodylomorph teeth, usually with a size between 1 and $2 \mathrm{~mm}$ in height, although some specimens smaller than $0.5 \mathrm{~mm}$ or around $1 \mathrm{~cm}$ in height were also found. Broken or very worn teeth have not been taken into account in the measurements table (see Appendix). The figured and measured specimens have been designated with the abbreviations MPZ (Museum of Natural Sciences of the University of Zaragoza). All teeth were examined under an Olympus SZ40 binocular microscope with an LC20 digital camera incorporated and a scanning electron microscope SEM JEOL JSM 6360 (20kV, Working Distance $=15 \mathrm{~mm}$ ) at the University of Zaragoza. The picture scaling and measurements were performed with the software Olympus LCmicro (developed by Olympus Soft Imaging Solutions) and ImageJ (rsb.info.nih.gov/).

The fossil vertebrate assemblage from the La Cantalera site described in this paper is housed in the Museo de Ciencias Naturales de la Universidad de Zaragoza (MPZ).

\section{SYSTEMATIC PALAEONTOLOGY}

Because of the great intraspecific variation in tooth morphology and a shortage of phylogenetic information, it is difficult to assign a taxonomic status at generic and even at family level to isolated teeth belonging to Crocodylomorpha (Prasad and Broin, 2002; Buscalioni et al., 2008). We have thus decided to be conservative with the taxonomic assignment of each morphotype.

Superorder CROCODYLOMORPHA Walker, 1970 (sensu Clark, 1986)

Clade MESOEUCROCODYLIA Whetstone and Whybrow, 1983 (sensu Benton and Clark, 1988) Clade NEOSUCHIA? Benton and Clark, 1988 Family GONIOPHOLIDIDAE? Cope, 1875 Genus and species undetermined Figure 3

Referred material. 169 isolated teeth $(46.30 \%$ of the sample = 365 teeth; MPZ 2014/468, 469, 470, 471a, 471b and 719 through 820).

Description. The referred teeth are represented by two different sizes, with large teeth ranging between 5 and $10 \mathrm{~mm}$ (Figure 3.1-2), and very small sizes ranging between 1 and $2 \mathrm{~mm}$ (Figure 3.3-4). They are conical in shape, with generalist forms having a circular cross-section, with medium to high crowns and a very acute apex that is slightly lingually curved. The lingual and labial surfaces are separated by smooth carinae, the labial surface being slightly more convex than the lingual 


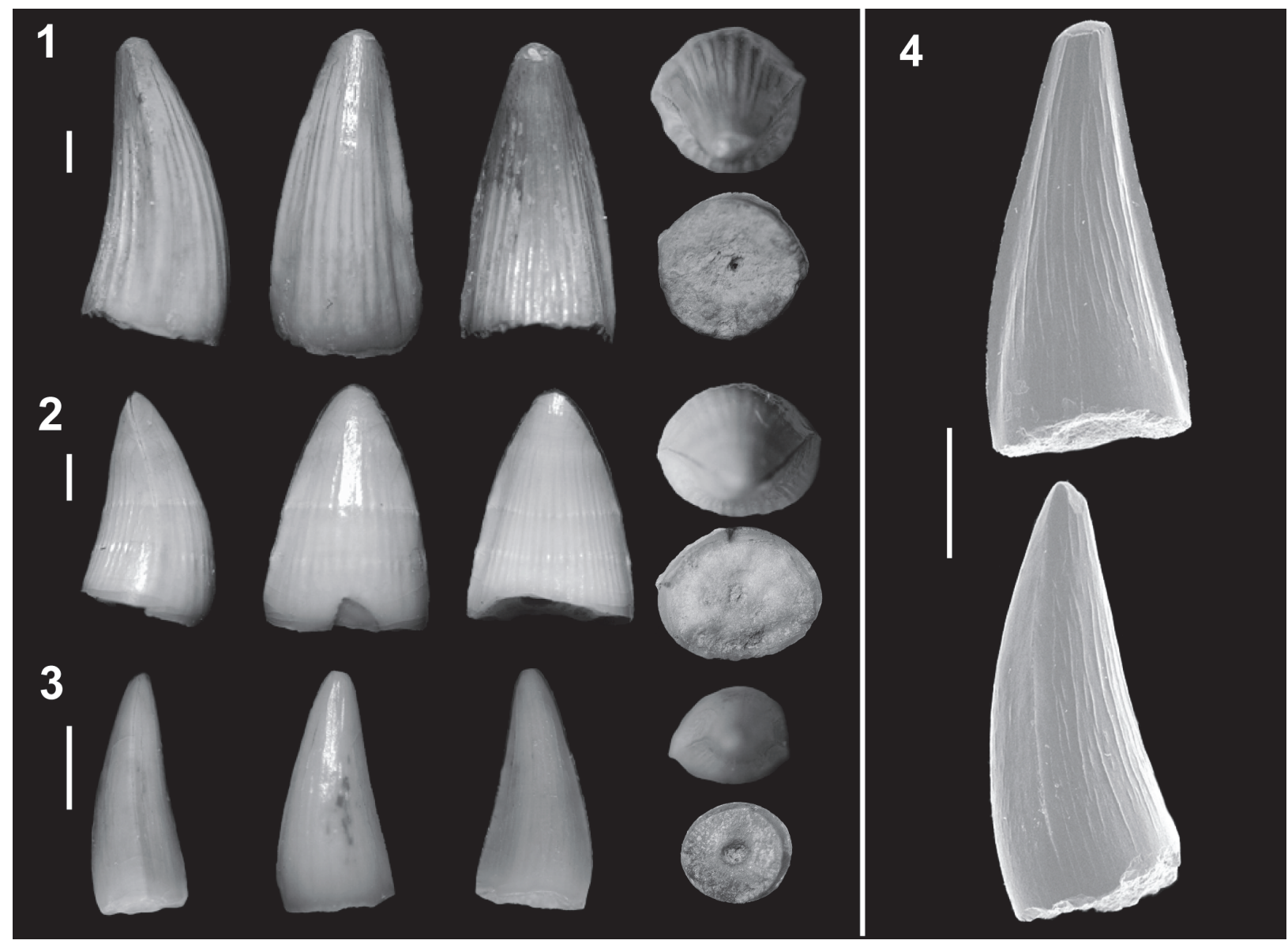

FIGURE 3. Crocodylomorph teeth attributed to Goniopholididae? from La Cantalera site. 1-3, MPZ 2014/468, 469 and 470; photographs taken with a binocular microscope in mesial/distal, labial, lingual, apical (above) and radicular (below) views. 4, photographs taken with a scanning electron microscope in labial (above, MPZ 2014/471a) and mesial/distal (below, MPZ 2014/471b) views. Scale bars equal $1 \mathrm{~mm}$.

face. The carinae show different degrees of development, being more marked in the smaller teeth (Figure 3.4). The transition between the tooth and root is almost unconstricted. In radicular view, the pulp cavity is short and shows subcircular morphology. Enamel ornamentation is formed by between five and 10 longitudinal and almost parallel ridges going straight from the base and converging slightly toward the apex. In some teeth, the longitudinal ridges next to the carinae of the lingual face seem to diverge.

Remarks. The dental morphologies described above are often attributed to Goniopholididae. Nevertheless, very similar teeth are also present in most neosuchians with generalist habits and diets, and they are also common in the anterior dental region of several crocodylomorphs with heterodont dentition, such as Bernissartia fagesii (Buffetaut and Ford, 1979) or Theriosuchus (Schwarz and Salisbury, 2005; Lauprasert et al., 2011; Martin et al., 2014). However, the high percentage of this form of tooth $(46.30 \%$ of the sample) is unlikely to have come from only teeth from the anterior positions of heterodont crocodylomorphs, so there is likely at least one taxon present at La Cantalera with a generalist dentition, such as Goniopholididae.

\section{Family BERNISSARTIIDAE? Dollo, 1883 \\ Genus and species undetermined Morphotype A \\ Figure 4.1-3}

Referred material. 104 isolated teeth $(28.49 \%$ of the sample = 365 teeth; MPZ 2014/472, 473, 474a, 474b and 843 through 901).

Description. Molariform or tribodont teeth, bulky, bulbous, rounded, with low crowns and a blunt apex. The teeth have circular, elliptical (Figure 4.2), kidney-shaped (Figure 4.3) or figure-eight-shaped cross-sections at their base (Figure 4.1). Certain specimens display stronger mediolateral compres- 

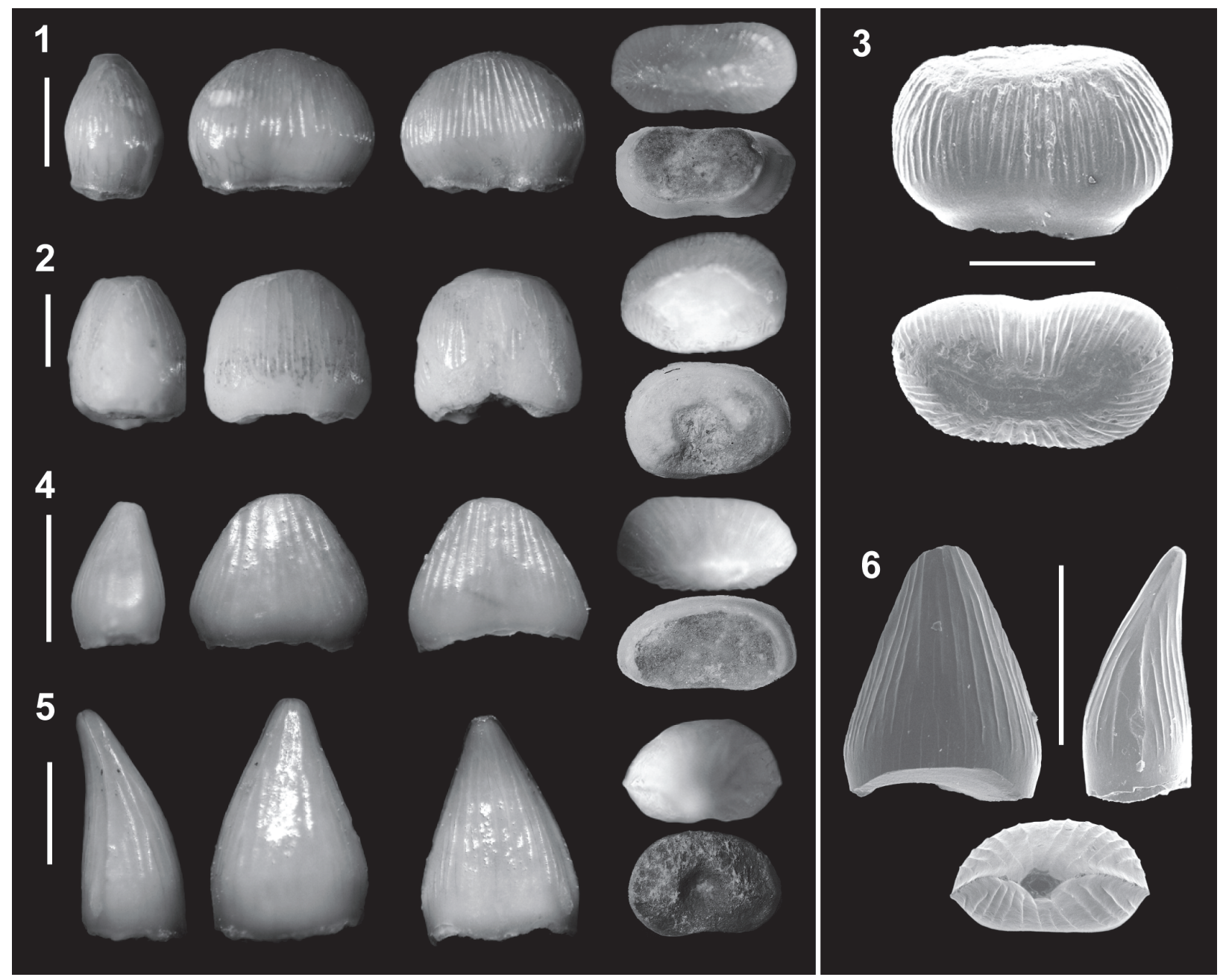

FIGURE 4. 1-3, MPZ 2014/472, 473, 474a and 474b; crocodylomorph teeth from La Cantalera site attributed to Bernissartiidae?; photographs taken with a binocular microscope $(1,2)$ in mesial/distal, labial, lingual, apical (above) and radicular (below) views; photographs taken with a scanning electron microscope (3) in lingual (MPZ 2014/474a, above) and apical (MPZ 2014/474b, below) views. 4-6, MPZ 2014/475, 476, 477a, 477b and 477c; crocodylomorph teeth from La Cantalera site attributed to Bernissartiidae?, which may correspond to teeth from the anterior or mid region of the tooth row; photographs taken with a binocular microscope $(4,5)$ in mesial/distal, labial, lingual, apical (above) and radicular (below) views; photographs taken with a scanning electron microscope (6) in labial (MPZ 2014/ 477a, left), mesial/distal (MPZ 2014/477b, right) and apical (MPZ 2014/477c, below) views. Scale bars equal $1 \mathrm{~mm}$.

sion than others (Figure 4.1), but they all show a rounded profile in lingual/labial view. The base of the crowns has a strong constriction. The pulp cavity, which can only be seen in a very few specimens because the root is not usually preserved, presents sub-ellipsoidal morphology, with the major axis running anteroposteriorly. Enamel ornamentation is formed by thin parallel ridges converging toward the apex. In most teeth, the presence of mesiodistal carinae is unlikely. However, in taller and less worn teeth a basiapical keel that is more marked towards the apex can be observed.
Within this morphotype there is some degree of variability according to the heterodont dentition observed in complete skulls and jaws of Bernissartia (Buffetaut and Ford, 1979; Buscalioni and Sanz, $1984,1990 \mathrm{~b})$. The teeth from the posterior region of the tooth row have lower crowns, kidney-shaped or figure-eight-shaped sections and greater lateral compression (Figure 4.1, 3). By contrast, the anteriorly placed teeth have morphologies with taller crowns and sub-ellipsoidal to circular sections, without figure-eight-shaped sections (Figure 4.1). Almost all teeth have a worn occlusal surface. 
Remarks. This morphotype has been assigned to Bernissartiidae? since this type of morphology is common in taxa of the same age, such as Bernissartia or Koumpiodontosuchus (Buffetaut and Ford, 1979; Sweetman et al., 2014). However, care must be taken with such specific assignments. This type of tooth, associated with a durophagous diet, is also present in other taxa not closely related with Bernissartiidae, such as Unasuchus, Acynodon, Allognathosuchus, Brachychampsa, Albertochampsa and the extant Osteolaemus (Buffetaut and Ford, 1979; Brinkmann, 1992; Buscalioni et al., 1997, 1999; Martin, 2007; Delfino et al., 2008). Therefore, the presence of this type of morphology may be more closely linked to dietary function than to phylogenetic relatedness (Buffetaut and Ford, 1979).

\section{Morphotype B \\ Figure 4.4-6}

Referred material. 62 isolated teeth $(16.98 \%$ of the sample = 365 teeth; MPZ 2014/475, 476, 477a, 477b, 477c and 902 through 962).

Description. These teeth are short and conical with a triangular outline in lingual/labial view and strong mediolateral compression. The crowns are relatively low and small in size (1-2 mm). The labial surface is convex, and the lingual face is slightly flattened. The apex is slightly lingually curved, and there are mesial and distal carinae. The root contour is somewhat constricted, and the pulp cavity has subcircular to ellipsoidal morphology that is elongate in an anteroposterior direction. On the lingual surface, the base of the tooth has a slight concavity, giving it a somewhat kidneyshaped cross-section at its base. The ornamentation consists of thin parallel longitudinal ridges that converge towards the apex on both sides.

Remarks. In previous papers, such teeth have been attributed to forms close to Lisboasaurus and the LH-Crocodyliform (crocodyliform from Las Hoyas, Cuenca, Spain) (Canudo et al., 2010) which are two mesoeucrocodylians from the Kimmeridgian / Barremian of Spain and Portugal (Buscalioni et al., 1996; Ortega, 2004; Schwarz and Fechner, 2004, 2008). The triangular profile with laterally compressed crowns and the presence of a lingual groove at the base of the crown are indeed reminiscent of teeth present in Lisboasaurus and the LH-Crocodyliform. However, the teeth from Lisboasaurus and the LH-Crocodyliform have completely smooth enamel, lacking carinae and ornamentation (Schwarz and Fechner, 2008). The ornamentation of this dental morphotype from $\mathrm{La}$ Cantalera and its constriction at the base of the crown are also consistent with teeth attributed to Bernissartiidae. The greater crown height and the more conical shape could correspond to teeth from anterior positions in the jaw or to unworn teeth from the mid region in the dental series of Bernissartiidae (Buffetaut and Ford, 1979; Buscalioni and Sanz, 1990b; Sweetman et al., 2014).

\section{Family ATOPOSAURIDAE Gervais, 1871 \\ Genus THERIOSUCHUS Owen, 1879 \\ Species undetermined \\ Figure 5}

Referred material. 26 isolated teeth $(7.12 \%$ of the sample $=365$ teeth; MPZ 2014/478, 479, 480, 481, 482a, 482b, 482c and 821 through 841).

Description. The teeth show the typical autapomorphic characters observed in the genus Theriosuchus, with dentition that comprises labiolingually compressed low-crowned, pseudocaniniform and lanceolate-shaped teeth, with mesial and distal carinae. The teeth are laterally compressed with differences in size. The labial surface is convex and flatter than the lingual face, with a slight curvature towards the lingual area near the apex. This morphotype shows morphological variability that can be related to different dental positions observed in skulls and jaws with preserved teeth of Theriosuchus (Owen, 1879; Brinkmann, 1992; Schwarz and Salisbury, 2005; Karl et al., 2006; Lauprasert et al., 2011; Martin et al., 2014). The teeth located in posterior positions of the tooth row (Figure 5.1-2, 5) are wider mesiodistally, highly laterally compressed, leaf-shaped and with a lower crown. The labial surfaces of these teeth are convex, and the lingual surfaces are flatter in the base and somewhat concave towards the apex. In addition, the radicular contour is slightly constricted, and the pulp cavity is completely flattened and elongated. By contrast, the teeth from anterior positions (Figure 5.3-4) are less laterally compressed, are lanceolate and have a considerably higher crown. They have mesial and distal carinae, but their torsion towards the lingual area is less pronounced. The pulp cavity is not as elongated or flattened, presenting an ellipsoidal morphology.

Remarks. Within this morphotype there exists great morphological variability associated with the enamel ornamentation and the presence or absence of true or false denticles on the carinae. Most teeth present longitudinal well-marked ridges, which are convergent in the central area of the tooth and diverge towards the carinae (Figure 5.1, 3,5 ); others have fine anastomosed striae (Figure 5.2), and yet others have almost smooth enamel 

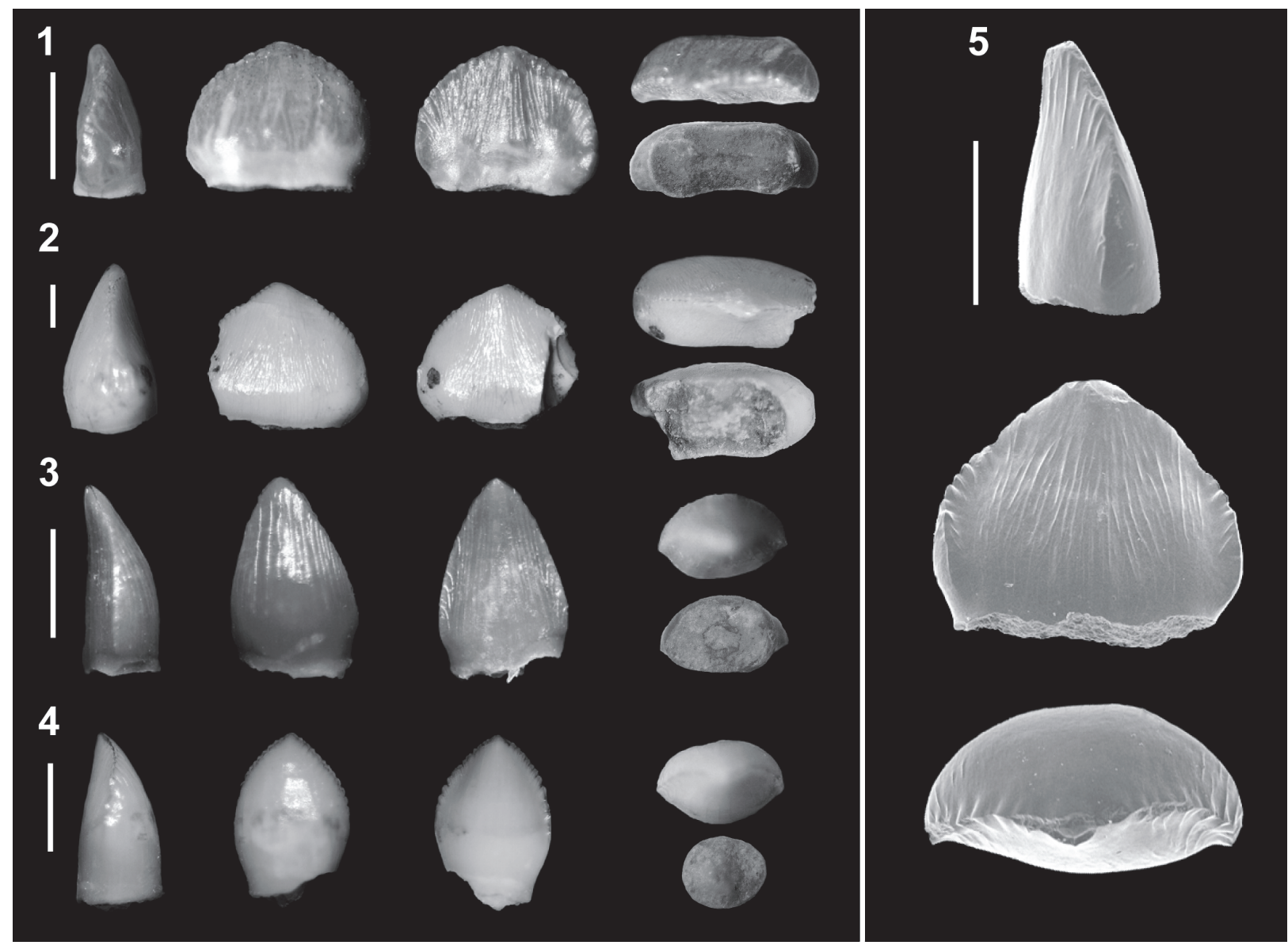

FIGURE 5. Crocodylomorph teeth attributed to Theriosuchus sp. from La Cantalera site. 1-4, MPZ 2014/478, 479, 480 and 481; photographs taken with a binocular microscope in mesial/distal, labial, lingual, apical (above) and radicular (below) views. 5, MPZ 2014/482a, 2014/482b and 2014/482c; photographs taken with a scanning electron microscope in mesial/distal (2014/482a, above), lingual (2014/482a, middle) and apical (2014/482a, below) views. Scale bars equal $1 \mathrm{~mm}$.

(Figure 5.4). This kind of tooth has been associated with insectivorous diets (Buscalioni and Sanz, 1988). The presence, absence and size of the denticles on the carinae seem to be related with the convergence of enamel ridges or grooves towards the carinae ("false ziphodont" according to Prasad and Broin, 2002). The size of the denticles are proportional to the thickness of the ridges. However, teeth with nearly smooth enamel may also have denticles (Figure 5.4). The presence of leaf-shaped or lanceolate teeth is probably related to the tooth position in the dental series, but the variation in the enamel ornamentation may be due to the presence of several taxa or great intraspecific variability. This kind of dental morphology is typical of atoposaurids such as Theriosuchus.

Clade MESOEUCROCODYLIA Whetstone and Whybrow, 1983 (sensu Benton and Clark, 1988)

\section{Family, Genus and species undetermined Figure 6.1}

Referred material. 3 isolated teeth $(0.82 \%$ of the sample = 365 teeth; MPZ 2014/483 and 842).

Description. Conical teeth with high crowns, a circular cross-section at the base and a sharp apex curved lingually and distally. Their relatively large size varies between 5 and $10 \mathrm{~mm}$. The enamel ornamentation is somewhat variable and may be smooth or with fine longitudinal ridges. The lingual and labial surfaces are separated by carinae with true denticles (ziphodont), with the labial surface slightly more convex than the lingual face. A tooth is ziphodont when the denticles are not the result of the prolongation of the enamel ridges (Prasad and Broin, 2002).

Remarks. The term "ziphodont" has long been applied to Mesoeucrocodylia, including several 


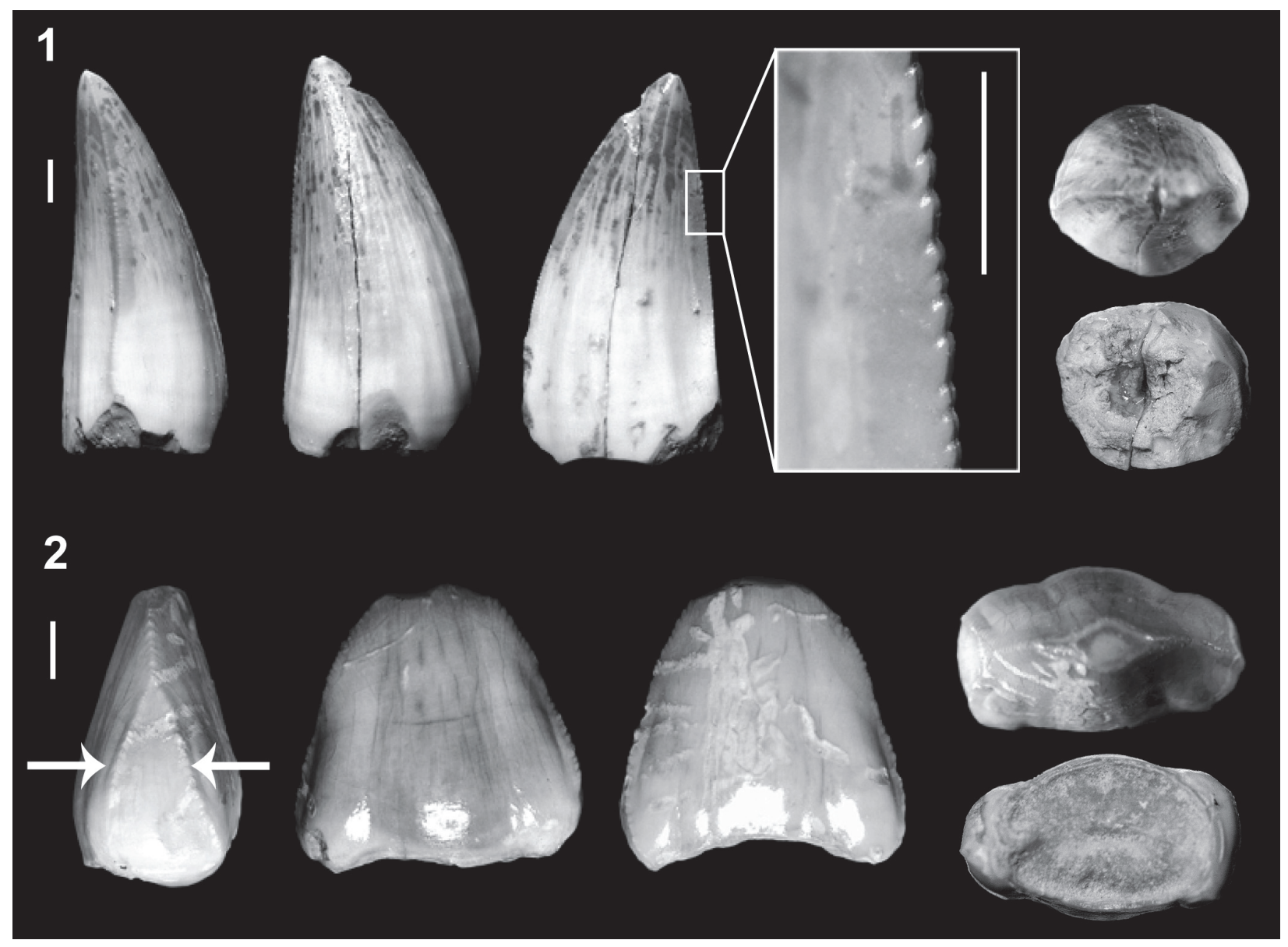

FIGURE 6. 1, MPZ 2014/483; ziphodont crocodylomorph tooth attributed to Mesoeucrocodylia indet. in mesial/distal, labial, lingual (with detail of the denticles), apical (above) and radicular (below) views. 2, MPZ 2014/484; bizarre crocodylomorph tooth attributed to Mesoeucrocodylia indet. in mesial/distal (arrows show the bifurcated keel), labial, lingual, apical (above) and radicular (below) views. All photographs taken with a binocular microscope. Scale bars equal $1 \mathrm{~mm}$.

genera from such a broad range of families that they may well not be monophyletic. Typical taxa with true ziphodont dentition are notosuchians, planocraniids and some peirosaurids. The use of ziphodont dentition as a criterion for the taxonomic classification of isolated teeth must thus be taken with caution since it is considered to be of limited value as phylogenetic information (Turner, 2006; Andrade and Bertini, 2008). This type of dentition was present in highly predatory terrestrial crocodylomorphs, thus having ecological rather than phylogenetic implications (Andrade and Bertini, 2008). For this reason, we have chosen to assign this morphotype to Mesoeucrocodylia indet.

Clade MESOEUCROCODYLIA Whetstone and Whybrow, 1983 (sensu Benton and Clark, 1988)

Family, Genus and species undetermined Figure 6.2
Material. 1 isolated tooth $(0.27 \%$ of the sample $=$ 365 teeth; MPZ 2014/484).

Description. Relatively large tooth (about $1 \mathrm{~cm}$ ) with spatulate morphology, mediolaterally compressed and with a low crown. The lingual and labial faces have two longitudinal grooves dividing the enamel into three bulbous surfaces that are more pronounced towards the base of the tooth. The enamel is smooth and has mesial and distal carinae with true denticles of variable size. One of the carinae forks into two at the base of the tooth.

Remarks. The overall tooth morphology resembles that of the spatulate teeth of Atoposauridae. However, we do not know other crocodylomorphs with this kind of enamel ornamentation and the presence of bifurcated carinae, so it has been assigned to Mesoeucrocodylia indet. Given that only one tooth with this strange morphology has been found, 
the carinae could be the result of some form of pathology.

\section{PALAEOECOLOGY}

The palaeontological site of La Cantalera was formed in a small basin, with no fluvial influence or allochthonous accumulation of sediments, and where most of the recovered fossils show no evidence of transport. La Cantalera has been interpreted as comprising floodplain deposits with ephemeral lacustrine episodes in an area of marshy vegetation (Aurell et al., 2004). The taphonomic, stratigraphic and sedimentological characteristics of La Cantalera indicate that the high concentration and biodiversity of vertebrates at the site is the result of sediment accumulation in a lentic ecosystem and not an accumulation caused by transport. It is therefore a site with a very concrete spatio-temporal distribution that shows the fauna that inhabited the area for a relatively short time interval (Canudo et al., 2010), and thus it is reasonable to assume sympatry of the species.

Given the faunal assemblage of a palaeontological site, it is possible to make predictions and interpretations about the type of ecosystem that occupied the area at the time (Buscalioni et al., 2008). The taxa of La Cantalera were divided into different groups (aquatic, amphibious and terrestrial) (Table 1) according to their dependence on water for extant wetlands (Valk, 2006; Buscalioni et al., 2008; Gasca et al., 2012). Gasca et al. (2012) proposed a simplified model based on Valk (2006), considering as aquatic taxa to organisms that cannot survive without the presence of water, such as fishes or aquatic algae. Amphibious taxa would be the species that spend part of their life cycle in water and part on terrestrial environments but they cannot survive if the wetland is totally drained, a good example would be the lissamphibians or some turtles and crocodiles. Terrestrial species are organisms that can be found both in wetlands and terrestrial environments and they can survive outside the wetland, such as lacertids, pterosaurs, dinosaurs and mammals. The results show that $16.21 \%$ of the organisms were aquatic, with two species of charophytes, two of gastropods, one of ostracod and just one osteichthyan fish. Amphibious organisms show a similar percentage at $18.91 \%$; these are composed of at least four crocodylomorphs, two lissamphibians and one turtle (very scarce). Terrestrial organisms show the highest percentage at $64.86 \%$, and these are made up of one lizard, two pterosaurs, 17 dinosaurs and four mammals.
The large number of terrestrial organisms in relation to the aquatic and amphibious fauna contrasts with the association expected in a wetland ecosystem, where aquatic and amphibious species are often the most abundant (Valk, 2006), as at other sites of similar age such as Buenache or Las Hoyas (Cuenca, Spain) (Buscalioni et al., 2008). The site of La Cantalera shows a faunal assemblage more similar to the site of Uña (Cuenca). However, the large number of terrestrial organisms in Uña is attributed to taphonomic and sedimentological factors, since the abundance of these organisms can be explained by transport and allochthonous sedimentation (Buscalioni et al., 2008). The scarce transport observed in La Cantalera, together with other factors such as the abundance of terrestrial organisms and the high number of replacement teeth of herbivorous dinosaurs, indicates that La Cantalera could have been an occasional feeding area for herbivorous dinosaurs, especially during wet periods (RuízOmeñaca et al., 1997).

Another remarkable thing in La Cantalera is the small size of the recovered remains. Except for some large bones belonging to dinosaurs, most of the remains are small teeth. This also applies to the crocodylomorphs, with tooth heights of between 1 and $2 \mathrm{~mm}$ on average, and only a few specimens are less than $0.5 \mathrm{~mm}$ or around $1 \mathrm{~cm}$ in height. $52.60 \%$ of the crocodylomorph teeth correspond to Bernissartiidae? and Atoposauridae. These taxa are characterized by their small body size, with a total length of around $50 \mathrm{~cm}$ in the adult stage and never exceeds $1 \mathrm{~m}$ in length (Buscalioni and Sanz, 1990a, 1990b, 1990c; Schwarz-Wings et al., 2009). Despite their small body size, the teeth of adult atoposaurids and bernissartiids were bigger than those from La Cantalera (average size of $1.79 \mathrm{~mm}$ for Theriosuchus sp. and $1.31 \mathrm{~mm}$ for Bernissartiidae?, see Appendix) and thus most of the teeth from La Cantalera likely belong to juveniles. For example, the teeth from adult specimens of Theriosuchus pusillus Owen, 1879 or Theriosuchus sympiestodon Martin, Rabi, Csiki-Sava and Vasile, 2014 range between $2 \mathrm{~mm}$ (posterior maxillary teeth) to $10 \mathrm{~mm}$ (enlarged fourth maxillary tooth) in height, while young individuals range between $1 \mathrm{~mm}$ (posterior maxillary teeth) to 3.5 $\mathrm{mm}$ (enlarged fourth maxillary tooth) in height; and the teeth from adult specimens of bernissartiids such as Koumpiodontosuchus or the holotype of Bernissartia from Belgium range between $3 \mathrm{~mm}$ to $6 \mathrm{~mm}$ in height (measurements taken from the figures of Owen (1879), Clark (1986) and Martin et al. 
(2014) for Theriosuchus; from Sweetman et al. (2014) for Koumpiodontosuchus; and firsthand measurements taken by us for Bernissartia). Therefore, the teeth from adult specimens of Theriosuchus or Bernissatiidae are above the $2 \mathrm{~mm}$ in height, while in juvenile specimens are usually less than $2 \mathrm{~mm}$ in height, with the exception of the 4th enlarged maxillary tooth which is usually greater than $2 \mathrm{~mm}$ in height. Given the small size of most of the teeth from La Cantalera attributed to Goniopholididae? (average size $=2.28 \mathrm{~mm}$, see Appendix), the presence of adult goniopholidids is ruled out, since this is a group that can reach up to $4 \mathrm{~m}$ of body length with teeth with an average size of 13 $\mathrm{mm}$ in the adult stage (Buscalioni et al., 2008). This argument would be strengthened because immature specimens of dwarf goniopholidids such as Nannosuchus gracilidens Owen, 1879 have teeth that vary between 2.5 to $7 \mathrm{~mm}$ in height (measurements taken from the plate 44 of Owen (1879)), which is the approximate size range observed in La Cantalera. The high concentration of probable juvenile crocodylomorphs and the abundant crocodylomorph eggshell fragments (Canudo et al., 2010; Moreno-Azanza et al., 2013) at the site of La Cantalera could be explained by the presence of a nearby nesting area. Extant crocodylomorphs, the hatchlings and juveniles usually remain around the nesting area and nearby areas with the mother for weeks or even until two seasons before dispersing; freshwater wetland areas/grasslands are the most common places for nesting (Brazaities and Watanabe, 2011).

\section{CONCLUSIONS}

La Cantalera has at least six morphotypes that could correspond to at least four different crocodylomorph taxa (Goniopholididae?, Bernissartiidae?, Theriosuchus and an undetermined ziphodont). Due to the high variability within each morphotype, especially those assigned to Theriosuchus, the presence of more than four different crocodylomorph species seems the most likely hypothesis.

The site has a similar crocodylomorph assemblage to other European Lower Cretaceous sites such as Bornholm (Denmark) and Buenache de la Sierra (Cuenca), where there is also an association of Goniopholididae, Bernissartiidae, Atoposauridae and an undetermined ziphodont (Buscalioni et al., 2008; Schwarz-Wings et al., 2009). We prefer not to assign the bizarre tooth with bifurcated carinae to any particular taxon, because there is only one isolated specimen with this morphology and it could be the result of pathology.

This site is also characterized by the absence of large individuals and by the presence of teeth with a wide variety of morphologies. Such tooth disparity has been explained in terms of a trophic diversity ranging from generalist to insectivorous and durophagous habits (Buscalioni and Sanz, 1988). Furthermore, this rich biodiversity could be due to the fact that in marsh ecosystems, especially during dry periods, vertebrates tend to occupy and move to areas that remain flooded, where water and food are more abundant. Another hypothesis that could explain the abundance of small teeth and the presence of crocodylomorph eggshell fragments is that La Cantalera was occasionally used as a nesting area

\section{ACKNOWLEDGEMENTS}

This work forms part of the European Regional Development Fund, the Government of Aragón ("Grupos Consolidados" and "Dirección General de Patrimonio Cultural") and the program Formación del Profesorado Universitario (FPU) subsidized by the Spanish Ministry of Education, Culture and Sports. The comments of Alexander Hastings have improved the original manuscript. Rupert Glasgow edited the text in English.

\section{REFERENCES}

Alcalá, L., Espílez, E., Mampel, L., Kirkland, J.I., Ortiga, M., Rubio, D., González, A., Ayala, D., Cobos, A., Royo-Torres, R., Gascó, F. and Pesquero, M.D. 2012. A new Lower Cretaceous vertebrate bonebed near Ariño (Teruel, Aragón, Spain); found and managed in a joint collaboration between a mining company and a palaeontological park. Geoheritage, 4:275-286.

Andrade, M.D. and Bertini, R.J. 2008. Morphology of the dental carinae in Mariliasuchus amarali (Crocodylomorpha, Notosuchia) and the pattern of tooth serration among basal Mesoeucrocodylia. Arquivos do Museu Nacional, 66(1):63-82.

Aurell, M., Bádenas, B., Canudo, J.I. and RuizOmeñaca, J.I. 2004. Evolución tectosedimentaria de la Fm. Blesa (Cretácico Inferior) en el entorno del yacimiento de vertebrados de la Cantalera (Josa, Teruel). Geogaceta, 35:11-13.

Badiola, A., Canudo, J.I. and Cuenca?Bescós, G. 2008. New multituberculate mammals from the Hauterivian/ Barremian transition of Europe (Iberian Peninsula). Palaeontology, 51(6):1455-1469.

Benton, M.J. and Clark, J.M. 1988. Archosaur phylogeny and the relationships of the Crocodylia, p. 295-338. In Benton, M.J. (ed.), The phylogeny and classifica- 
tion of tetrapods, vol. 1, amphibians, reptiles, birds. Clarendon Press, Oxford.

Brazaitis, P. and Watanabe, M.E. 2011. Crocodilian behavior: a window to dinosaur behaviour?. Historical Biology, 23(1):73-90.

Brinkmann, W. 1992. Die krokodilier-fauna aus der Unter-Kreide (Ober-Barremium) von Uña (Provinz Cuenca, Spanien). Berliner Geowissenschaftliche Abhandlungen, (E), 5:1-123.

Buffetaut, E. and Ford, R.L.E. 1979. The crocodilian Bernissartia in the Wealden of the Isle of Wight. Palaeontology, 22:905-912.

Buscalioni, A.D., Alcalá, L., Espílez, E. and Mampel, L. 2013. European Goniopholididae from the early Albian Escucha Formation in Ariño (Teruel, Aragón, España). Spanish Journal of Paleontology 28(1):103-122.

Buscalioni, A.D., Buffetaut, E. and Sanz, J.L. 1984. An immature specimen of the crocodilian Bernissartia from the Lower Cretaceous of Galve (province of Teruel, Spain). Paleontology, 27(4):809-813.

Buscalioni, A.D., Frenegal, M.A., Bravo, A., PoyatoAriza, F.J., Sanchíz, B., Báez, A.M., Cambra Moo, O., Martín Closas, C., Evans, S.E. and Marugán Lobón, J. 2008. The vertebrate assemblage of Buenache de la Sierra (upper Barremian of Serrania de Cuenca, Spain) with insights into its taphonomy and palaeoecology. Cretaceous Research, 29:687-710.

Buscalioni, A.D., Ortega, F., Pérez-Moreno, B.P. and Evans, S.E. 1996. The Upper Jurassic maniraptoran theropod Lisboasaurus estesi (Guimarota, Portugal) reinterpreted as a crocodylomorph. Journal of Vertebrate Paleontology, 16(2):358-362.

Buscalioni, A.D., Ortega, F. and Vasse, D. 1997. New crocodiles (Eusuchia: Alligatoroidea) from the Upper Cretaceous of southern Europe. Comptes Rendus de l'Académie des Sciences-Series IIA-Earth and Planetary Science, 325:525-530.

Buscalioni, A.D., Ortega, F. and Vasse, D. 1999. The Upper Cretaceous crocodilian assemblage from Laño (Northcentral Spain): implications in the knowledge of the finicretaceous European faunas. Estudios del Museo de Ciencias Naturales de Alava, 14:213-233.

Buscalioni, A.D. and Sanz, J.L. 1984. Los Arcosaurios (Reptilia) del Jurásico Superior-Cretácico Inferior de Galve (Teruel, España). Teruel, 71:9-30.

Buscalioni, A.D. and Sanz, J.L. 1987. Cocodrilos del Cretácico inferior de Galve (Teruel, España). Estudios Geológicos, volumen Extraordinario GalveTremp (1987), 23-43.

Buscalioni, A.D. and Sanz, J.L. 1988. Phylogenetic relationships of the Atoposauridae (Archosauria, Crocodylomorpha). Historical Biology, 1(3):233-250.

Buscalioni, A.D. and Sanz, J.L. 1990a. Montsecosuchus depereti (Crocodylomorpha, Atoposauridae), new denomination for Alligatorium depereti Vidal, 1915 (early Cretaceous, Spain): redescription and phylo- genetic relationships. Journal of Vertebrate Paleontology, 10(2):244-254.

Buscalioni, A.D. and Sanz, J.L. 1990b. The small crocodile Bernissartia fagesii from the Lower Cretaceous of Galve (Teruel, Spain). Bulletin-Institut Royal des sciences naturelles de Belgique. Sciences de la terre, 60:129-150.

Buscalioni, A.D. and Sanz J.L. 1990c. La familia Atoposauridae: una aproximación a la historia de los cocodrilos enanos. Treballs del Museu de Geologia de Barcelona 1:77-89.

Canudo, J.I., Aurell, M., Barco, J.L., Cobos, A., CuencaBescós, G., Martín-Closas, C., Murelaga, X., PeredaSuberbiola, X., Royo-Torres, R. and Ruiz-Omeñaca, J.I. 2002b. La Cantalera: Un resumen de los dinosaurios del tránsito Hauteriviense-Barremiense (Cretácico inferior) de la Cordillera Ibérica (Josa, Teruel), p. 27-28. In Libro de Resúmenes. XVIII Jornadas de la Sociedad Española de Paleontología. II Congreso Ibérico de Paleontología, Salamanca.

Canudo, J.I., Gasca, J.M., Aurell, M., Badiola, A., Blain, H.-A., Cruzado- Caballero, P., Gómez-Fernández, D., Moreno-Azanza, M., Parrilla, J., Rabal, R. and Ruiz-Omeñaca, J.I. 2010. La Cantalera: an exceptional window onto the vertebrate biodiversity of the Hauterivian-Barremian transition in the Iberian Peninsula. Journal of Iberian Geology, 36(2):205-224.

Canudo, J.I., Gasca, J.M., Moreno, M. and Aurell, M. 2012. New information about the stratigraphic position and age of the sauropod Aragosaurus ischiaticus from the Early Cretaceous of the Iberian Peninsula. Geological Magazine, 149(2):252-263.

Canudo, J.I., Ruiz-Omeñaca, J.I., Barco, J.L. and RoyoTorres, R. 2002a. ¿Saurópodos asiáticos en el Barremiense Inferior (Cretácico Inferior) de España?. Ameghiniana 39(4):443-452.

Canudo, J.I., Ruiz-Omeñaca, J.I. and Cuenca-Bescós, G. 2004. Los primeros dientes de anquilosaurio (Ornithischia: Thyreophora) descritos en el Cretácico Inferior de España. Revista Española de Paleontología, 19(1):33-46.

Clark, J.M. 1986. Phylogenetic relationships of the Crocodylomorph Archosaurs. Unpublished PhD Thesis, University of Chicago, Illinois, USA, 556 pp.

Cope, E.D. 1875. Check-list of North American Batrachia and Reptilia with a systematic list of the higher groups and an essay on geographical distribution based on the specimens in the U.S. National Museum. Bulletin of the United States National Museum, l:1-104.

Cuenca-Bescós, G. and Canudo, J.I. 2003. A new gobiconodontid mammal from the Early Cretaceous of Spain and its palaeobiogeographical implications. Acta Palaeontologica Polonica, 48:575-582.

Delfino, M., Martin, J.E. and Buffetaut, E. 2008. A new species of Acynodon (Crocodylia) from the upper cretaceous (Santonian-Campanian) of Villaggio del Pescatore, Italy. Palaeontology, 51(5):1091-1106. 
Dollo, L. 1883. Premiere note sur les Crocodiliens de Bernissart. Bulletin Musee Royal Histoire Naturelle de Belgique, 2:309-338.

Gasca, J.M., Badiola, A., Canudo, J.I., Moreno-Azanza, M. and Puértolas, E. 2012. The fossil vertebrate assemblage from the Pochancalo 1 site (Valanginian-Hauterivian, Villanueva de Huerva, Zaragoza, Spain). Actas de V Jornadas Internacionales sobre Paleontología de Dinosaurios y su Entorno, Salas de los Infantes, Burgos, 159-172.

Gasca, J.M., Canudo, J.I. and Moreno-Azanza, M. 2014. On the diversity of Iberian iguanodont dinosaurs: new fossils from the lower Barremian, Teruel province, Spain. Cretaceous Research, 50:264-272.

Gervais, P. 1871. Remarques au sujet des Reptiles provenant des calcaires lithographiques de Cerin, dans le Bugey, qui sont conservés au Musée de Lyon. Comptes Rendus des Séances de l'Academie de Sciences, 79-83.

Grambast, L. 1968. Evolution of the utricule in the Charophyte genera Perimneste Harris and Atopochara Peck. Journal of the Linnean Society of London (Botany), 61(384):5-11.

Karl, H.V., Gröning, E., Brauckmann, C., Schwarz, D. and Knötschke, N. 2006. The Late Jurassic crocodiles of the Langenberg near Oker, Lower Saxony (Germany), and description of related materials (with remarks on the history of quarrying the "Langenberg Limestone" and "Obernkirchen Sandstone"). Clausthaler Geowissenschaften, 5:59-77.

Kneuper-Haack, F. 1966. Ostracoden aus dem Wealden der Sierra de los Cameros (Nordwestliche Iberische Ketten). Beihefte zum Geologischen Jahrbuch, 44:165-209.

Lauprasert, K., Laojumpon, C., Saenphala, W., Cuny, G., Thirakhupt, K. and Suteethorn, V. 2011. Atoposaurid crocodyliforms from the Khorat Group of Thailand: First record of Theriosuchus from Southeast Asia. Palaontologische Zeitschrift, 85:37-47.

Martin, J.E. 2007. New material of the Late Cretaceous globidontan Acynodon iberoccitanus (Crocodylia) from southern France. Journal of Vertebrate Paleontology, 27(2):362-372.

Martin, J.E., Rabi, M., Csiki-Sava, Z. and Vasile, S. 2014. Cranial morphology of Theriosuchus sympiestodon (Mesoeucrocodylia, Atoposauridae) and the widespread occurrence of Theriosuchus in the Late Cretaceous of Europe. Journal of Paleontology, 88(3):444-456.

Moreno-Azanza, M., Canudo, J.I. and Gasca, J.M. 2014. Unusual theropod eggshells from the Early Cretaceous Blesa Formation of the Iberian Range, Spain. Acta Paleontologica Polonica, 59(4):843-854.

Moreno-Azanza, M., Gasca, J.M. and Canudo, J.I. 2009. A high diversity eggshell locality from the Hauterivian-Barremian transition of the Iberia Peninsula. Journal of Vertebrate Paleontology, 29(supplement to number 3):151A.
Ortega, F. 2004. Historia evolutiva de los cocodrilos Mesoeucrocodylia. Unpublished Ph.D. Thesis, Universidad Autónoma de Madrid, Madrid, Spain.

Ortega, F., García, J.J.M., García, J.L.S., Buscalioni, A.D., Valbuena, J. and Jiménez, S. 1996. Sobre la presencia de un cocodrilo fósil (Crocodylomorpha: Neosuchia: "Goniopholis" sp.) en la cuenca de Cameros (Cretácico inferior: Vadillos-San Román de Cameros, La Rioja). Zubía, 14:113-120.

Owen, R. 1879. Monograph on the fossil reptilia of the Wealden and Purbeck formations. Supplement No. IX, Crocodilia (Goniopholis, Brachydectes, Nannosuchus, Theriosuchus and Nuthetes). Monograph of the Palaeontographical Society, 33(155):1-19.

Prasad, G.V. and de Lapparent de Broin, F. 2002. Late Cretaceous crocodile remains from Naskal (India): comparisons and biogeographic affinities. Annales de Paléontologie, 88(1):19-71.

Puértolas-Pascual, E. and Canudo, J.I. 2013. Dermal skeleton of a lower Albian goniopholidid (Crocodylomorpha, Neosuchia) from Andorra (Teruel, Spain): biomechanical implications, p. 115-117. In Torcida, F. and Huerta, P. (eds.), Libro de Resúmenes de las VI Jornadas Internacionales sobre Paleontología de Dinosaurios y su entorno. Salas de los Infantes, Burgos.

Puértolas-Pascual, E., Canudo, J.I. and Sender, L.M. 2015. New material from a huge specimen of Anteophthalmosuchus cf. escuchae (Goniopholididae) from the Albian of Andorra (Teruel, Spain): Phylogenetic implications. Journal of Iberian Geology, 41(1): 41-56.

Puértolas-Pascual, E., Moreno-Azanza, M. and Canudo, J.I. 2012. Primer registro de un cocodrilomorfo (Neosuchia, Goniopholididae?) en la Formación Escucha (Albiense inferior) de la mina Corta Barrabasa (Teruel), p. 94-96. In Martínez-Pérez, C., Furió, M., Santos-Cubedo, A. and Poza, B. (eds.), Libro de Resúmenes del $X$ Encuentro de Jóvenes Investigadores en Paleontología. Paleodiversity and Paleoecology of Iberian Ecosystems, Sot de Chera.

Rauhut, O.W.M. 2002. Dinosaur teeth from the Barremian of Uña, Province of Cuenca, Spain. Cretaceous Research, 23:255-263.

Ruiz-Omeñaca, J.I. and Canudo, J. I. 2001. Dos yacimientos excepcionales con vertebrados continentales del Barremiense (Cretácico Inferior) de Teruel: Vallipón y La Cantalera. Naturaleza Aragonesa, 8:8-17.

Ruiz-Omeñaca, J.I., Canudo, J.I., Aurell, M., Badenas, B., Cuenca-Bescós, G. and Ipas, J. 2004. Estado de las investigaciones sobre los vertebrados del Jurásico Superior y el Cretácico Inferior de Galve (Teruel). Estudios Geológicos, 60:179-202.

Ruiz-Omeñaca, J.I., Canudo, J.I. and Bescós, G.C. 1997. Primera evidencia de un área de alimentación de dinosaurios herbívoros en el Cretácico Inferior de España (Teruel). Monografías de la Academia de 
Ciencias Exactas, Físicas, Químicas y Naturales de Zaragoza, 10:1-48.

Salas, R., Guimerà, J., Más, R., Martín-Closas, C., Meléndez, A. and Alonso, A. 2001. Evolution of the mesozoic central iberian rift system and its cainozoic inversion (Iberian Chain). Mémoires du Muséum Nationale de l'Histoire Naturelle, 186:145-185.

Sanz, J.L., Buscalioni, AD., Casanovas, M.L. and Santafé, J.V. 1984. The archosaur fauna from the Upper Jurassic / Lower Cretaceous of Galve (Teruel, Spain). Third Symposium on Mesozoic Terrestrial Ecosystems, 207-210.

Schwarz, D. and Fechner, R. 2004. Lusitanisuchus, a new generic name for Lisboasaurus mitracostatus (Crocodylomorpha: Mesoeucrocodylia), with a description of new remains from the Upper Jurassic (Kimmeridgian) and Lower Cretaceous (Berriasian) of Portugal. Canadian Journal of Earth Sciences, 41(10):1259-1271.

Schwarz, D. and Fechner, R. 2008. The first dentary of Lisboasaurus (Crocodylomorpha?, Mesoeucrocodylia) from the Lower Cretaceous (Barremian) of Uña, Cuenca Province, Spain. Journal of Vertebrate Paleontology, 28(1):264-268.

Schwarz-Wings, D., Rees, J. and Lindgren, J. 2009. Lower Cretaceous Mesoeucrocodylians from Scandinavia (Denmark and Sweden). Cretaceous Research, 30:1345-1355.

Schwarz, D. and Salisbury, S.W. 2005. A new species of Theriosuchus (Atoposauridae, Crocodylomorpha) from the Late Jurassic (Kimmeridgian) of Guimarota, Portugal. Geobios, 38:779-802.

Soria, A.R., Martín-Closas, C., Meléndez, A., Meléndez, N. and Aurell, M. 1995. Estratigrafía del Cretácico inferior del sector central de la Cordillera Ibérica. Estudios Geológicos, 51:141-152.

Soria de Miguel, A.R. 1997. La sedimentación en las cuencas marginales del Surco Ibérico durante el Cretácico Inferior y su contorno estructural. Unpublished PhD Thesis, Universidad de Zaragoza, Zaragoza, Spain.

Sweetman, S.C., Pedreira-Segade, U. and Vidovic, S. 2014. A new bernissartiid crocodyliform from the Barremian Wessex Formation (Wealden Group) of the Isle of Wight, southern England. Acta Palaeontologica Polonica. doi:dx.doi.org/10.4202/app.00038.2013

Turner, A.H. 2006. Osteology and phylogeny of a new species of Araripesuchus (Crocodyliformes: Mesoeucrocodylia) from the Late Cretaceous of Madagascar. Historical Biology, 18(3):255-369.

van der Valk, A.G. 2006. The biology of freshwater wetlands. Oxford University Press, Oxford.

Walker, A.D. 1970. A revision of the Jurassic reptile Hallopus victor (Marsh), with remarks on the classification of crocodiles. Philosophical Transactions Royal Society London, Ser. B, 257:323-372.

Whetstone, K.N. and Whybrow, P.J. 1983. A "cursorial" crocodilian from the Triassic of Lesotho (Basutoland), southern Africa. Occasional Papers of the Museum of Natural History. The University of Kansas, 106:137. 
PuÉrtolas-Pascual, Rabal-Garcés, \& Ignacio CANudo: Biodiversity of "LA CANTAlera”

\section{APPENDIX - TEETH MEASUREMENTS}

Appendix material is available online at

palaeo-electronica.org/content/2015/1229-biodiversity-of-la-cantalera 